\title{
Management of Older Patients With
}

\section{Metastatic Renal Cell Carcinoma}

\section{Receiving Sunitinib: A Hypothetical, Illustrative Case Scenario}

SUSAN K. ROETHKE, ${ }^{1}$ CRNP, MSN, ANP-BC, AOCNP ${ }^{\circledR}$, JOANNE C. RYAN, ${ }^{2}$ PhD, RN, and SARAH YENSER WOOD, ${ }^{3}$ RN, MSN, ANP, AOCNP ${ }^{\circledR}$

From 'Fox Chase Cancer Center, Philadelphia, Pennsylvania; 'Pfizer Oncology, US Medical Affairs, New York, New York; ${ }^{3}$ Duke Prostate Center, Durham, North Carolina

Authors' disclosures of conflicts of interest are found at the end of this article.

Correspondence to: Joanne C. Ryan, PhD, RN, Pfizer Oncology, 235 E 42nd St, New York, NY 10017. E-mail: joanne.c.ryan@pfizer.com https://doi.org/10.6004/jadpro.2018.9.1.5 (c) 2018 Harborside $^{\mathrm{TM}}$

\section{CASE STUDY}

Tom, a 75-year-old white male, was recently diagnosed with metastatic renal cell carcinoma (RCC; Tom's case is not an actual clinical case but has been developed by the authors as an exemplar). Two years prior, he had undergone a left partial (laparoscopic) nephrectomy for clear cell RCC. At that time, he had a stage 3 disease (the tumor extended into perinephric tissues but not into the ipsilateral adrenal gland and not beyond Gerota's fascia [Cancer.net, 2016]), and regularly (every 3-6 months) scheduled surveillance imaging did not show metastatic disease. Recent imaging with a computed tomography (CT) of the chest/ abdomen/pelvis revealed small bilateral pulmonary nodules that did not have the radiographic appearance of a primary lung tumor, but rather that of metastatic disease. Therefore, a decision was made to repeat CT scans in a shorter interval (in 6 weeks) to assess growth kinetics. Subsequent CT scan showed an increase in size and number of pulmonary nodules, so the decision was made to begin systemic treatment.

At the time of Tom's metastatic evaluation, his Eastern Cooperative Oncology Group performance status was $O$ as he was asymptomatic and fully active (Table 1). He was classified as favorable risk according to Heng criteria (Table 2). Tom is married and lives with his wife. He is independent in his self-care but also relies on his wife for health-care decision-making. He does not drink alcohol and is a former smoker with a history of 30 pack-years. Tom's medical history includes hypertension that is adequately controlled with lisinopril (20 mg/day), coronary artery disease (on daily aspirin $81 \mathrm{mg}$ ) with left ventricular ejection fraction (LVEF) of $>50 \%$, which is within the normal range (50\%-75\%), benign prostatic hyperplasia for which he is treated with finasteride, and hyperlipidemia that is treated with atorvastatin. 


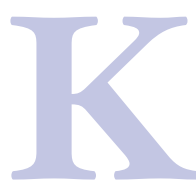

idney cancer represents $3.7 \%$ of all adult cancers in the United States, with 62,700 new cases and 14,240 deaths estimated in 2016 (SEER Cancer Statistics Factsheets, 2016). Renal cell carcinoma (RCC) accounts for $90 \%$ of kidney cancer and $70 \%$ to $75 \%$ of RCC cases are of clear-cell histology (Muglia \& Prando, 2015). Up to $40 \%$ of patients diagnosed with RCC will eventually develop metastatic disease (Janowitz, Welsh, Zaki, Mulders, \& Eisen, 2013; Thorstenson et al., 2015). The introduction of anti-angiogenesis targeted therapies, including inhibitors of the vascular endothelial growth factor (VEGF)-pathway and the mammalian target of rapamycin, dramatically increased the treatment options for metastatic RCC (mRCC) and improved clinical outcomes in those patients (Thomas \& Kabbinavar, 2015).

Approximately half of all patients diagnosed with RCC are age $\geq 65$ years, and almost $70 \%$ of those patients die from this disease (SEER Cancer Statistics Factsheets, 2016). However, older ( $\geq 65$ years) patients tend to be underrepresented in clinical trials investigating new cancer therapies (Scher \& Hurria, 2012; Talarico, Chen, \& Pazdur, 2004). This is primarily due to the assumption that targeted therapy may not be well-tolerated due to the increased comorbid conditions and the use of multiple medications that can lead to increased incidences of adverse events, drug-drug interactions, and nonadherence to therapy (National Comprehensive Cancer Network [NCCN]
Guidelines, 2016a). The NCCN Guidelines divide older patients into 3 categories: (1) young-old patients, aged 65 to 75 years; (2) old patients, aged 76 to 85 years; and (3) oldest-old patients, aged $\geq 85$ years.

Although prospective studies in older patients are lacking, retrospective analyses demonstrated that older ( $\geq 65$ years) patients with mRCC treated with targeted therapy experienced similar efficacy as younger ( $<65$ years) patients and had generally similar safety profiles, with some adverse events more frequently reported in older patients (Hutson et al., 2014; Khambati et al., 2014; Porta et al., 2012; Procopio et al., 2012; Zanardi et al., 2016). These findings support using targeted therapy in older patients with mRCC; however, closer monitoring for potential adverse events is warranted.

\section{TREATMENT}

Based on NCCN Guidelines for first-line treatment of patients who relapsed after nephrectomy, Tom was prescribed $50 \mathrm{mg}$ /day of sunitinib (Sutent) on a 4-weeks-on/2-weeks-off treatment schedule (schedule 4/2), to total a 6-week cycle. Sunitinib is frequently provided as one $50-\mathrm{mg}$ capsule to be taken orally once daily; however, Tom was given a prescription of 12.5-mg capsules for ease of potential dose titration. Tom was monitored closely via telephone on day 7 and with an office visit after 2 weeks of commencing treatment with sunitinib. Both Tom and his wife were educated about dosing and expectations of sunitinib therapy. Tom's wife can be instrumental in helping Tom adhere to his

\begin{tabular}{|c|c|c|}
\hline Grade & Description & Status \\
\hline 0 & Asymptomatic & Fully active, able to carry on all pre-disease activities without restriction \\
\hline 1 & $\begin{array}{l}\text { Symptomatic but completely } \\
\text { ambulatory }\end{array}$ & $\begin{array}{l}\text { Restricted in physically strenuous activity but ambulatory and able to carry } \\
\text { out work of a light or sedentary nature. For example, light housework, } \\
\text { office work }\end{array}$ \\
\hline 2 & $\begin{array}{l}\text { Symptomatic, }<50 \% \text { in bed } \\
\text { during the day }\end{array}$ & $\begin{array}{l}\text { Ambulatory and capable of all self-care but unable to carry out any work } \\
\text { activities. Up and about more than } 50 \% \text { of waking hours }\end{array}$ \\
\hline 3 & $\begin{array}{l}\text { Symptomatic, }>50 \% \text { in bed, but } \\
\text { not bedbound }\end{array}$ & $\begin{array}{l}\text { Capable of only limited self-care, confined to bed or chair } 50 \% \text { or more of } \\
\text { waking hours }\end{array}$ \\
\hline 4 & Bedbound & $\begin{array}{l}\text { Completely disabled. Cannot carry on any self-care. Totally confined to } \\
\text { bed or chair }\end{array}$ \\
\hline 5 & Dead & \\
\hline
\end{tabular}




\section{Table 2. Heng Prognostic Criteria for Metastatic Renal Cell Carcinoma}

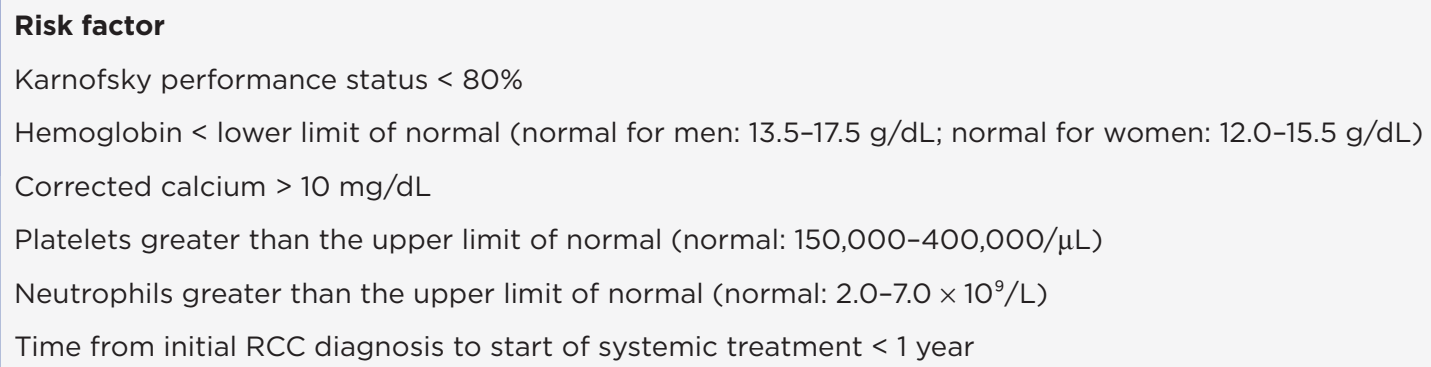

therapy and report his adverse events in a timely and accurate fashion. Within week 2 to 3 of the first cycle, he was found to have a rising blood pressure (> 150/90 $\mathrm{mmHg}$; grade 2 hypertension), onset of grade 2 hand-foot syndrome (HFS; Figure 1), grade 1 mucositis (a "functional" mucositis with no evidence of redness and/or lesions), grade 1 nausea, dyspepsia, fatigue, and some loose bowel movements (but not diarrhea). The daily dose of lisinopril was increased to $40 \mathrm{mg}$ to control his blood pressure and he was instructed to continue to monitor blood pressure at home on a daily basis, and to call the office if readings are $>150 / 90$ mmHg. All of his other symptoms, including fatigue, peaked by week 4 , but subsided within 5 days off sunitinib treatment. He was started on ranitidine $150 \mathrm{mg}$ twice daily for the nausea and dyspepsia. To treat the "functional" mucositis, Tom was initially advised to rinse using salt water or baking soda with water but when it got worse, a swish and spit of $5 \mathrm{~mL}$ of steroid-based rinse containing hydrocortisone 4 times a day was recommended. Tom was also advised to use children's toothpaste, and to avoid acidic/spicy foods and alcohol-based mouthwash. Tom was instructed to take loperamide ( $2 \mathrm{mg}$ after the first loose stool, and $1 \mathrm{mg}$ after each additional loose stool, with a maximum of 8 tablets per 24 hours) and to maintain his hydration while having loose stools. To address the soreness of the soles of his feet, Tom was counseled to apply plenty of emollient lotions on his feet, and use gel inserts in his shoes.
Subsequent assessment at the beginning of cycle 2 revealed stable blood pressure and reduction of other symptoms to grade 0 to 1 , except the pain and erythema in his feet. During week 2 to 3 of cycle 2, the HFS (pain and yellow calluses with ery-

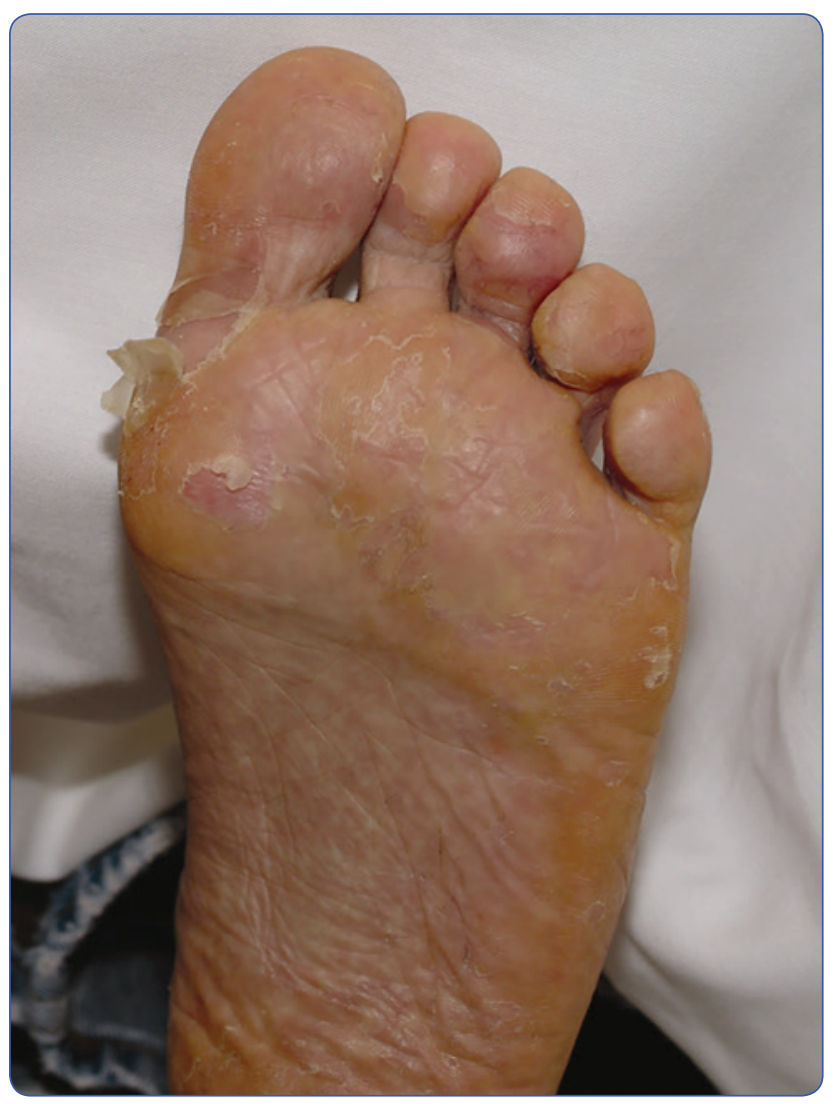

Figure 1. Grade 2 hand-foot syndrome. Courtesy of Cleveland Clinic Taussig Cancer Center. 
thema surrounding them [Figure 2]) on the heels and balls of his feet progressed to grade 3 (Figure 3). Sunitinib was held for a week until the symptoms reduced to grade 1 , and Tom was able to finish the cycle. For the third cycle, the dosing schedule was changed to a 2 -weeks-on/1-week-off treatment schedule (schedule 2/1) in an attempt to improve tolerance. This change in schedule still maintains a 6-week cycle where the patient receives a total of 4 weeks of $50 \mathrm{mg}$ of sunitinib and a 2 -week break, but the treatment breaks are redistributed ( 2 weeks of sunitinib followed by a 1-week break and repeated once to conclude the full 6-week cycle). At a minimum, complete blood counts (CBC) and comprehensive metabolic panel (CMP) were monitored at the start of each cycle. Thyroid-stimulating hormone (TSH) and T4 levels were monitored every 8 to 12 weeks. In the fourth cycle, Tom was found to have grade 2 hypothyroidism; TSH was elevated, confirmed by abnormal free T4 levels, and he began treatment with levothyroxine $25 \mu \mathrm{g}$ daily. Tom's TSH and T4 levels were monitored every 4 to 6 weeks to evaluate the need for dose titration.

\section{OUTCOME}

A follow-up CT of chest/abdomen/pelvis at 3 months after sunitinib treatment initiation revealed stable disease and no new metastasis de-

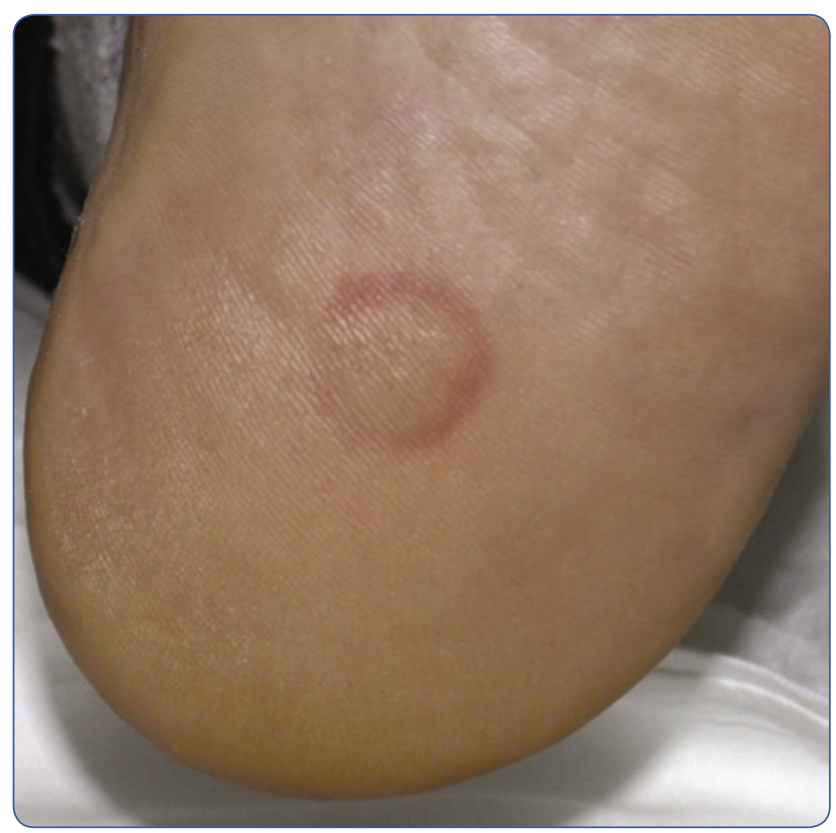

Figure 2. Grade 2 heel callus with erythema. Courtesy of Cleveland Clinic Taussig Cancer Center. tected. Subsequent CT scans showed a decrease in size and number of pulmonary nodules, indicating ongoing response to treatment. Through effective management of adverse events, Tom was able to stay on and tolerate sunitinib treatment, ultimately using schedule $2 / 1$. He required no further dose interruptions or adjustments and is now receiving cycle 5 .

\section{DISCUSSION}

The NCCN Guidelines recommend consideration of first-line systemic therapy if relapse occurs after nephrectomy. First-line therapy (category 1) recommendations include sunitinib, bevacizumab (Avastin) plus interferon-alfa, pazopanib (Votrient), and also temsirolimus (Torisel) for patients with poor prognosis (NCCN Guidelines, 2016b). Only a few of these drugs, including sunitinib, bevacizumab, and temsirolimus, have been evaluated in older patients with mRCC; both temsirolimus and bevacizumab showed greater efficacy in younger ( $<65$ years) patients (Escudier et al.,

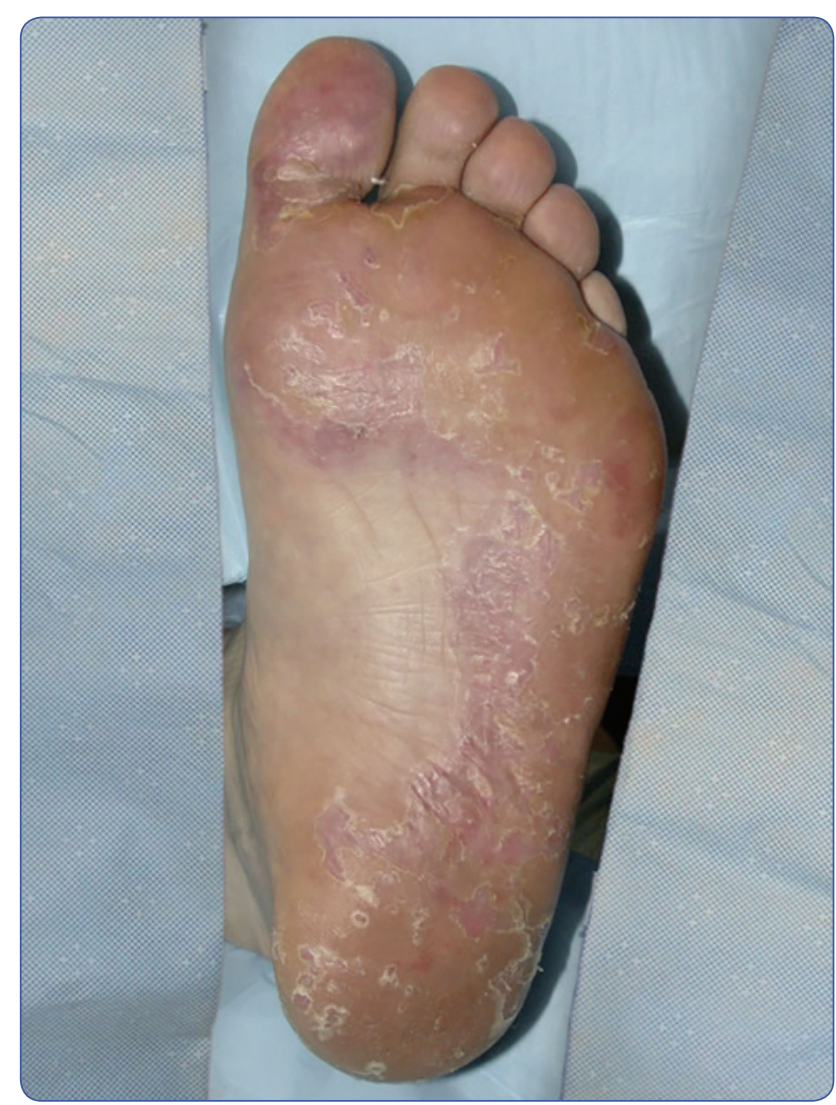

Figure 3. Grade 3 hand-foot syndrome. Courtesy of Cleveland Clinic Taussig Cancer Center. 
2010; Gore et al., 2009; Hudes et al., 2007; Hutson et al., 2014).

Sunitinib malate, an oral small-molecule multi-targeted tyrosine kinase inhibitor, is approved globally for the treatment of advanced RCC (Pfizer Inc., 2006). Since its approval by the US Food and Drug Administration (FDA) in January 2006, sunitinib has remained a first-line treatment option for advanced RCC per NCCN Guidelines. A retrospective analysis of pooled data from 6 clinical studies showed that sunitinib had comparable efficacy in older ( $\geq 70$ years) and younger ( $<70$ years) patients with mRCC (Hutson et al., 2014). Similar results were found in an expanded access trial of sunitinib in which median overall survival for patients aged $\geq 65$ years was comparable to that of the overall population (Gore et al., 2009). Additionally, a pooled analysis of patients with mRCC treated with sunitinib showed that favorable-risk level at baseline was associated with greater survival benefit compared with intermediate or poor risk (Motzer et al., 2013).

The beneficial clinical outcome achieved with sunitinib in older patients and in those with favorable risk at baseline, and the ease of administration (taken orally), made sunitinib a good treatment option for Tom.

\section{Optimization of Sunitinib Treatment Outcome in Older Patients With mRCC}

Advanced practice providers (APPs) have a central role in managing patients receiving sunitinib therapy and in optimizing treatment outcome. Good understanding of mRCC and the NCCN Guidelines for treating $\mathrm{mRCC}$ is critical. Information on mRCC, and specifically in older ( $\geq 65$ years) patients with mRCC, can be found on several websites, including websites for the National Cancer Institute, UpToDate, and NCCN (NCCN Guidelines, 2016a, 2016b). Additionally, older patients should also be assessed for socioeconomic challenges (e.g., living condition, social support, income, transportation/access barriers, and insurance), and for geriatric syndromes (e.g., functional dependency, mobility problems, falls, dementia, delirium, depression, nutritional deficiency, and polypharmacy; NCCN Guidelines, 2016a), which should be accounted for in treatment decisionmaking and therapy management.
When initiating any cancer therapy, it is essential to establish a plan for regular communication with the patient (and/or caregiver) in order to identify and manage adverse events proactively. This includes clear instructions of how and when to contact the provider's office. Including caregivers or family members in these discussions will help to promote adherence and reporting of side effects. Adherence may also be improved through the use of a pill caddy, diary, phone applications, alarms, adhesive daily medication reminders, etc. If patients miss a dose of sunitinib, we advise them to take the missed dose as soon as they remember. However, if it is almost time for the next scheduled dose, we recommend skipping the missed dose and going back to the normal dosing schedule. Patients who accidently take an overdose of sunitinib should be advised to seek emergency medical care.

In our practices, we see sunitinib-treated patients for adverse events assessment at weeks 2 and 4 of cycle 1 and in subsequent cycles on day 28 to 42 ; with many patients it may be best to see them at the end of the treatment cycle to evaluate the full extent of their side effects and laboratory changes. The grade level of adverse events is determined based on the Common Terminology Criteria for Adverse Events (CTCAE) Version 4.0 (U.S. Department of Health and Human Services, 2010). If a patient lives far from the office, we plan an additional telephone call at week 2. Patients are instructed to monitor blood pressure at home on a daily basis, and to call the office if readings are $>150 / 90 \mathrm{mmHg}$ (either value). To avoid hypotension, particularly in the elderly, it is important not to overtreat hypertension and to continue closely monitoring blood pressure when off therapy (i.e., 1- or 2 -week break). Patients are also asked to call the office if they experience diarrhea, nausea, skin changes, stomatitis, or anything that interferes with their ability to eat or drink fluids. We stress the importance of early reporting of side effects, with a goal of managing symptoms to enable them to stay on treatment. It is important to note that older patients have increased risk for dehydration. If dehydration occurs, careful monitoring and encouraging fluid intake is required especially when it is combined with sto- 
matitis, nausea, vomiting, or diarrhea. If needed, intravenous hydration should be initiated as soon as possible. Proton-pump inhibitors or H2 blockers may be prescribed for nausea. It is also important to remind the patient to stop taking laxatives if developing diarrhea. Closer investigation of the nature of the diarrhea (e.g., onset, frequency, and character of stools) may help suggest potential interventions such as psyllium products (bulking agent), loperamide, or diphenoxylate/atropine.

In addition, we do a baseline evaluation of $\mathrm{CBC}, \mathrm{CMP}$, TSH, electrocardiogram, and echocardiogram, or multigated acquisition scan (if a recent scan is not available). At the beginning of each treatment cycle CBC and CMP are assessed. It is important to note that repeating these lab tests at the end of the active treatment part of the cycle (i.e., day 28 in schedule $4 / 2$ or day 14 in schedule $2 / 1$ ) can aid in the identification of adverse events and allow for early intervention. Thyroid-stimulating hormone is measured every 8 to 12 weeks unless more frequent tests are clinically indicated, as in the case of managing treatment-induced hypothyroidism. Computed tomography of chest/ abdomen/pelvis (or magnetic resonance imaging [MRI] if necessary) should be conducted every 12 weeks, or as clinically indicated. Other imaging studies such as bone scan or brain/spine MRI may be used if clinically warranted.

\section{Strategies for Successful Management of Adverse Events}

It is very important to educate the patient (and caregiver) about adverse events that are known to be associated with sunitinib treatment and to encourage them to report them as soon as possible, as it may help patients remain on sunitinib therapy and potentially achieve a better outcome. A list of common treatment-emergent adverse events reported in the pivotal trial with sunitinib is shown in Table 3. Adverse events that were significantly more commonly reported by older ( $\geq 70$ years) patients based on a retrospective analysis of data from sunitinib trials are presented in Table 4 (Hutson et al., 2014). The relative higher incidence of anemia, thrombocytopenia, and weight changes in the patients $>70$ years highlights the need for extra vigilance in patient monitoring and assessments.

Although reducing the dose of sunitinib (dose reduction) is one approach to managing adverse events, another strategy may be to utilize an alternate dosing schedule, such as schedule 2/1 for sunitinib therapy. Published retrospective analyses suggest efficacy was comparable and safety was more manageable with schedule $2 / 1$ compared with schedule $4 / 2$ dosing of sunitinib (Atkinson et al., 2014; Khosravan, Motzer, Fumagalli, \& Rini, 2016; Kondo et al., 2014; Najjar et al., 2014).

\begin{tabular}{|lrr}
\hline Table 3. Treatment-Emergent Adverse Events Reported by $\mathbf{2} \mathbf{1 0} \%$ of Sunitinib-Treated Patients \\
\hline & \multicolumn{2}{c}{$\mathbf{n}=\mathbf{3 7 5} \mathbf{n}(\%)$} \\
\cline { 2 - 3 } Adverse reaction & All grades & $\mathbf{G r a d e ~} \mathbf{3 / 4}$ \\
Diarrhea & $246(66)$ & $37(10)$ \\
Fatigue & $233(62)$ & $55(15)$ \\
Nausea & $216(58)$ & $21(6)$ \\
Anorexia (including decreased appetite) & $182(48)$ & $11(3)$ \\
Mucositis/stomatitis & $178(47)$ & $13(3)$ \\
Altered taste (including ageusia, hypogeusia, and dysgeusia) & $178(47)$ & $1(<1)$ \\
Pain in extremity/limb discomfort & $150(40)$ & $19(5)$ \\
Vomiting & $148(39)$ & $19(5)$ \\
Bleeding, all sites & $140(37)$ & $16(4)$ \\
Dyspepsia & $128(34)$ & $8(2)$
\end{tabular}

Note. GERD = gastroesophageal reflux disease. Results from the pivotal phase III clinical study with sunitinib vs. IFN- $\alpha$ (Pfizer Inc, 2006). 
Table 3. Treatment-Emergent Adverse Events Reported by $\geq 10 \%$ of Sunitinib-Treated Patients (cont.)

\section{Adverse reaction}

Hypertension

Abdominal pain

Arthralgia

Rash

Hand-foot syndrome

Back pain

Cough

Dyspnea

Asthenia

Skin discoloration/yellow skin

Edema, peripheral

Headache

Constipation

Dry skin

Fever

Hair color changes

Ejection fraction decreased

Hypothyroidism

Weight decreased

Insomnia

Oral pain

Nasopharyngitis

Chills

Flatulence

Alopecia

Oropharyngeal pain

Chest pain

Dry mouth

GERD/reflux esophagitis

Erythema

Pruritus

Dizziness

Upper respiratory tract infection

Depression

Glossodynia

Hemorrhoids

$n=375$ n (\%)

\section{All grades}

127 (34)

113 (30)

111 (30)

109 (29)

108 (29)

105 (28)

100 (27)

99 (26)

96 (26)

94 (25)

91 (24)

$86(23)$

85 (23)

$85(23)$

$84(22)$

$75(20)$

61 (16)

61 (16)

60 (16)

57 (15)

54 (14)

54 (14)

53 (14)

52 (14)

51 (14)

51 (14)

50 (13)

50 (13)

47 (12)

46 (12)

44 (12)

43 (11)

43 (11)

40 (11)

40 (11)

38 (10)
Grade 3/4

50 (13)

20 (5)

10 (3)

6 (2)

32 (8)

19 (5)

3 (1)

24 (6)

$42(11)$

1 (< 1)

7 (2)

4 (1)

4 (1)

1 (<1)

3 (1)

10 (3)

6 (2)

$1(<1)$

$3(<1)$

2 (<1)

$3(1)$

0

$$
0
$$

2 (< 1)

7 (2)

$$
0
$$

1 (< 1)

2 (<1)

$1(<1)$

2 (<1)

2 (<1)

0

0

0

Note. GERD = gastroesophageal reflux disease. Results from the pivotal phase III clinical study with sunitinib vs. IFN- $\alpha$ (Pfizer Inc, 2006). 


\begin{tabular}{|c|c|c|}
\hline \multirow[b]{2}{*}{ Adverse event } & \multicolumn{2}{|c|}{ n (\%) } \\
\hline & Age $\geq 70$ years $(n=202)$ & Age $<70$ years $(n=857)$ \\
\hline Fatigue & 139 (69) & $510(60)$ \\
\hline Cough & 59 (29) & $172(20)$ \\
\hline Anemia & $51(25)$ & $150(18)$ \\
\hline Peripheral edema & $54(27)$ & $144(17)$ \\
\hline Thrombocytopenia & $50(25)$ & $135(16)$ \\
\hline Weight decreased & $49(24)$ & $134(16)$ \\
\hline Appetite decreased & $58(29)$ & $114(13)$ \\
\hline Dizziness & 38 (19) & $102(12)$ \\
\hline Hypothyroidism & 35 (17) & $88(10)$ \\
\hline Dehydration & $36(18)$ & $82(10)$ \\
\hline Urinary tract infection & $29(14)$ & $32(4)$ \\
\hline
\end{tabular}

Note. $\mathrm{mRCC}=$ metastatic renal cell carcinoma. Information from Hutson et al. (2014).

a $p<.05$

Nonetheless, it is important to understand that some, but not all adverse events may be managed with dose adjustments. Some adverse events may be managed by supportive medications and/or lifestyle changes (i.e., diet and exercise) or dose interruptions. Because sunitinib is metabolized primarily by the cytochrome P450 enzyme CYP3A4, it is important to ask the patient about concomitant medications and consider potential drug-drug interactions with sunitinib. If inducers or inhibitors of CYP3A4 must be coadministered with sunitinib, a dose adjustment may be required (Table 5; Pfizer Inc, 2006).
Furthermore, it has been reported that there may be a benefit associated with the incidence of some adverse events. Prospective and retrospective studies showed that certain adverse events, including hypertension, HSF, asthenia and/or fatigue, neutropenia and thrombocytopenia, may be predictive of clinical outcome in patients with $\mathrm{mRCC}$ treated with inhibitors of the VEGF pathway (Davis et al., 2011; Di Fiore, Rigal, Menager, Michel, \& Pfister, 2011; Donskov et al., 2011; Donskov et al., 2015; Michaelson et al., 2011; Poprach et al., 2012; Rini et al., 2011; Rini et al., 2015; Soerensen et al., 2016; Yada et al., 2014).

Table 5. Potential Drug Interactions With Sunitiniba

\begin{tabular}{|c|c|c|c|}
\hline Drug category & Drug effect & Examples & Action \\
\hline $\begin{array}{l}\text { Strong CYP3A4 } \\
\text { inhibitors }\end{array}$ & $\begin{array}{l}\text { Increase sunitinib } \\
\text { plasma concentrations }\end{array}$ & $\begin{array}{l}\text { Ketoconazole, itraconazole, } \\
\text { clarithromycin, atazanavir, } \\
\text { indinavir, nefazodone, nelfinavir, } \\
\text { ritonavir, saquinavir, telithromycin, } \\
\text { voriconazole, grapefruit }\end{array}$ & $\begin{array}{l}\text { - Alternative medication with no } \\
\text { or minimal enzyme inhibition } \\
\text { potential is recommended } \\
\text { - A dose decrease should be } \\
\text { considered }\end{array}$ \\
\hline $\begin{array}{l}\text { Inducers of the } \\
\text { CYP3A4 pathway }\end{array}$ & $\begin{array}{l}\text { Decrease sunitinib } \\
\text { plasma concentrations }\end{array}$ & $\begin{array}{l}\text { Dexamethasone, phenytoin, } \\
\text { carbamazepine, rifampin, rifabutin, } \\
\text { rifapentine, phenobarbital, St. } \\
\text { John's wort }\end{array}$ & $\begin{array}{l}\text { - Alternative medication with no } \\
\text { or minimal enzyme induction } \\
\text { potential is recommended } \\
\text { - A dose increase should be } \\
\text { considered } \\
\text { - Do not take St. John's wort } \\
\text { concomitantly }\end{array}$ \\
\hline
\end{tabular}




\section{Paying for Sunitinib}

Patients may require assistance in evaluating their insurance coverage and to direct them to appropriate copay assistance options if needed. In addition, patients are given information about the Pfizer RxPathways program that helps to determine if a patient is eligible to receive sunitinib at no cost. Patients in Tom's age group who are Medicare beneficiaries may join a Part D drug coverage plan or obtain a supplemental plan that includes prescription coverage.

\section{CONCLUSIONS}

Advanced practice providers play a critical role in the management and support of older patients with mRCC. Advanced practice providers should be aware that an alternative dosing strategy exists for $\mathrm{mRCC}$ patients receiving sunitinib therapy who have trouble tolerating the schedule $4 / 2$. The literature shows that older patients with comorbidities can be treated with sunitinib by using an approach of close monitoring, aggressive adverse events/ symptom management, and switching to schedule $2 / 1$. This schedule enables patients to receive 50 $\mathrm{mg}$ /day of sunitinib for 4 weeks out of the 6-week cycle by redistributing the 2 -week break throughout the cycle (1-week-off therapy after each 2-weeks-on therapy). Frequent assessments and open communication with patients enable early identification of adverse events, timely schedule modifications, and may ultimately contribute to treatment success.

\section{Acknowledgment}

Medical writing support was provided by Vardit Dror, $\mathrm{PhD}$, of Engage Scientific Solutions and funded by Pfizer.

\section{Disclosure}

Ms. Wood received consulting fees from Exelixis and was a speaker for Pfizer and Exelixis. Ms. Roethke is on a speakers bureau for Pfizer, and served on a multidisciplinary advisory board for AstraZeneca. Dr. Ryan is an employee of and owns stock in Pfizer.

\section{References}

Atkinson, B. J., Kalra, S., Wang, X., Bathala, T., Corn, P., Tannir, N. M., \& Jonasch, E. (2014). Clinical outcomes for patients with metastatic renal cell carcinoma treated with alternative sunitinib schedules. Journal of Urology, 191(3), 611-618. http://doi.org/10.1016/j.juro.2013.08.090
Cancer.net. (2016). Kidney cancer: Stages. Retrieved from http:// www.cancer.net/cancer-types/kidney-cancer/stages

Davis, M. P., Figlin, R. A., Hutson, T. E., Goldstein, D., Li, S., Perkins, J., \& Motzer, R. J. (2011). Asthenia and fatigue as potential biomarkers of sunitinib efficacy in metastatic renal cell carcinoma. European Journal of Cancer, 47(suppl 1), S135 (poster 1139). http://dx.doi.org/10.1016/ S0959-8049(11)70782-1

Di Fiore, F., Rigal, O., Menager, C., Michel, P., \& Pfister, C. (2011). Severe clinical toxicities are correlated with survival in patients with advanced renal cell carcinoma treated with sunitinib and sorafenib. British Journal of Cancer, 105(12), 1811-1813. http://doi.org/10.1038/bjc.2011.507

Donskov, F., Carus, A., Barrios, C. H., Escudier, B., Li, S., Perkins, J., \& Motzer, R. J. (2011). Neutropenia and thrombocytopenia during treatment as biomarkers of sunitinib efficacy in patients with metastatic renal cell carcinoma (mRCC). European Journal of Cancer, 47(suppl 1), S136 (poster 1141). http://dx.doi.org/10.1016/S0959-8049(11)70784-5

Donskov, F., Michaelson, M. D., Puzanov, I., Davis, M. P., Bjarnason, G. A., Motzer, R. J.,...Rini, B. I. (2015). Sunitinibassociated hypertension and neutropenia as efficacy biomarkers in metastatic renal cell carcinoma patients. British Journal of Cancer, 113(11), 1571-1580. http://doi. org/10.1038/bjc.2015.368

Escudier, B., Bellmunt, J., Negrier, S., Bajetta, E., Melichar, B., Bracarda, S.,...Sneller, V. (2010). Phase III trial of bevacizumab plus interferon alfa-2a in patients with metastatic renal cell carcinoma (AVOREN): Final analysis of overall survival. Journal of Clinical Oncology, 28(13), 2144-2150. http://doi.org/10.1200/JCO.2009.26.7849

Gore, M. E., Szczylik, C., Porta, C., Bracarda, S., Bjarnason, G. A., Oudard, S.,...Bukowski, R. (2009). Safety and efficacy of sunitinib for metastatic renal-cell carcinoma: An expanded-access trial. Lancet Oncology, 10(8), 757-763. http://doi.org/10.1016/S1470-2045(09)70162-7

Heng, D. Y., Xie, W., Regan, M. M., Warren, M. A., Golshayan, A. R., Sahi, C.,...Choueiri, T. K. (2009) Prognostic factors for overall survival in patients with metastatic renal cell carcinoma treated with vascular endothelial growth factor-targeted agents: results from a large, multicenter study. Journal of Clinical Oncology, 27(34), 5794-5799. http://doi.org/10.1200/JCO.2008.21.4809

Hudes, G., Carducci, M., Tomczak, P., Dutcher, J., Figlin, R., Kapoor, A.,...Motzer, R. J. (2007). Temsirolimus, interferon alfa, or both for advanced renal-cell carcinoma. New England Journal of Medicine, 356(22), 2271-2281. http:// doi.org/10.1056/NEJMoa066838

Hutson, T. E., Bukowski, R. M., Rini, B. I., Gore, M. E., Larkin, J. M., Figlin, R. A.,...Motzer, R. J. (2014). Efficacy and safety of sunitinib in elderly patients with metastatic renal cell carcinoma. British Journal of Cancer, 110(5), 1125-1132. http://doi.org/10.1038/bjc.2013.832

Janowitz, T., Welsh, S. J., Zaki, K., Mulders, P., \& Eisen, T. (2013). Adjuvant therapy in renal cell carcinoma-past, present, and future. Seminars in Oncology, 40(4), 482491. http://doi.org/10.1053/j.seminoncol.2013.05.004

Khambati, H. K., Choueiri, T. K., Kollmannsberger, C. K., North, S., Bjarnason, G. A., Vaishampayan, U. N.,...Heng, D. Y. (2014). Efficacy of targeted therapy for metastatic renal cell carcinoma in the elderly patient population. Clinical Genitourinary Cancer, 12(5), 354-358. http://doi. org/10.1016/j.clgc.2014.02.009 
Khosravan, R., Motzer, R. J., Fumagalli, E., \& Rini, B. I. (2016). Population pharmacokinetic/pharmacodynamic modeling of sunitinib by dosing schedule in patients with advanced renal cell carcinoma or gastrointestinal stromal tumor. Clinical Pharmacokinetics, 55(10), 1251-1269. http://doi.org/10.1007/s40262-016-0404-5

Kondo, T., Takagi, T., Kobayashi, H., Iizuka, J., Nozaki, T., Hashimoto, Y.,...Tanabe, K. (2014). Superior tolerability of altered dosing schedule of sunitinib with 2-weeks-on and 1-week-off in patients with metastatic renal cell carcinoma-comparison to standard dosing schedule of 4-weekson and 2-weeks-off. Japanese Journal of Clinical Oncology, 44(3), 270-277. http://doi.org/10.1093/jjco/hyt232

Michaelson, M. D., Cohen, D. P., Li, S., Motzer, R. J., Escudier, B., Barrios, C. H.,...Puzanov, I. (2011). Hand-foot syndrome as a potential biomarker of efficacy in patients with metastatic renal cell carcinoma treated with sunitinib [Abstract 320]. Journal of Clinical Oncology (Annual Meeting Abstracts), 29(suppl 7).

Motzer, R. J., Escudier, B., Bukowski, R., Rini, B. I., Hutson, T. E., Barrios, C. H.,...Gore, M. E. (2013). Prognostic factors for survival in 1059 patients treated with sunitinib for metastatic renal cell carcinoma. British Journal of Cancer, 108(12), 2470-2477. http://doi.org/10.1038/bjc.2013.236

Muglia, V. F., \& Prando, A. (2015) Renal cell carcinoma: Histological classification and correlation with imaging findings. Radiologia Brasileira, 48(3), 166-174. http://doi. org/10.1590/0100-3984.2013.1927

Najjar, Y. G., Mittal, K., Elson, P., Wood, L., Garcia, J. A., Dreicer, R., \& Rini, B. I. (2014). A 2 weeks on and 1 week off schedule of sunitinib is associated with decreased toxicity in metastatic renal cell carcinoma. European Journal of Cancer, 50(6), 1084-1089. http://doi.org/10.1016/j.ejca.2014.01.025

National Comprehensive Cancer Network. (2016b). NCCN Clinical Practice Guidelines in Oncology: Kidney cancer. v2.2015. Retrieved from http://www.nccn.org/professionals/physician_gls/PDF/kidney.pdf

National Comprehensive Cancer Network. (2016a). NCCN Clinical Practice Guidelines in Oncology: Older adult oncology. v1.2016. Retrieved from https://www.nccn.org/ professionals/physician_gls/pdf/senior.pdf

Oken, M. M., Creech, R. H., Tormey, D. C., Horton, J., Davis, T. E., McFadden, E. T., \& Carbone, P. P. (1982). Toxicity and response criteria of the Eastern Cooperative Oncology Group. American Journal of Clinical Oncology, 5(6), 649-655.

Pfizer Inc. (2006). Sutent (sunitinib malate) package insert. Retrieved from http://labeling.pfizer.com/ShowLabeling. aspx? $\mathrm{id}=607$

Poprach, A., Pavlik, T., Melichar, B., Puzanov, I., Dusek, L., Bortlicek, Z.,...Buchler, T. (2012). Skin toxicity and efficacy of sunitinib and sorafenib in metastatic renal cell carcinoma: A national registry-based study. Annals of Oncology, 23(12), 3137-3143. http://doi.org/10.1093/annonc/mds145

Porta, C., Calvo, E., Climent, M. A., Vaishampayan, U., Osanto, S., Ravaud, A.,...Motzer, R. J. (2012). Efficacy and safety of everolimus in elderly patients with metastatic renal cell carcinoma: An exploratory analysis of the outcomes of elderly patients in the RECORD-1 Trial. European Urology, 61(4), 826-833. http://doi.org/10.1016/j.eururo.2011.12.057

Procopio, G., Verzoni, E., \& De Braud, F. (2012). Re: Camillo
Porta, Emiliano Calvo, Miguel A. Climent, et al. Efficacy and safety of everolimus in elderly patients with metastatic renal cell carcinoma: An exploratory analysis of the outcomes of elderly patients in the RECORD-1 Trial. European Urolology, 62(1), e5-e6. http://doi.org/10.1016/j. eururo.2012.03.048

Rini, B. I., Cohen, D. P., Lu, D. R., Chen, I., Hariharan, S., Gore, M. E.,...Motzer, R. J. (2011). Hypertension as a biomarker of efficacy in patients with metastatic renal cell carcinoma treated with sunitinib. Journal of the National Cancer Institute, 103(9), 763-773. http://doi.org/10.1093/jnci/djr128

Rini, B. I., Melichar, B., Fishman, M. N., Oya, M., Pithavala, Y. K., Chen, Y.,...Grunwald, V. (2015) Axitinib dose titration: Analyses of exposure, blood pressure and clinical response from a randomized phase II study in metastatic renal cell carcinoma. Annals of Oncology, 26(7), 13721377. http://doi.org/10.1093/annonc/mdv103.

Scher, K. S., \& Hurria, A. (2012) Under-representation of older adults in cancer registration trials: known problem, little progress. Journal of Clinical Oncology, 30(17), 2036-2038. http://doi.org/10.1200/JCO.2012.41.6727

SEER Cancer Statistics Factsheets. (2016). Kidney and renal pelvis cancer. Retrieved from http://seer.cancer.gov/ statfacts/html/kidrp.html

Soerensen, A. V., Geertsen, P. F., Christensen, I. J., Hermann, G. G., Jensen, N. V., Fode, K.,...Donskov, F. (2016). A five-factor biomarker profile obtained week 4-12 of treatment for improved prognostication in metastatic renal cell carcinoma: Results from DARENCA study 2. Acta Oncologica, 55(3), 341-348. http://doi.org/10.3109/0284186x.2015.1091499

Talarico, L., Chen, G., \& Pazdur, R. (2004). Enrollment of elderly patients in clinical trials for cancer drug registration: A 7-year experience by the US Food and Drug Administration. Journal of Clinical Oncology, 22(22), 4626-4631. http://doi.org/10.1200/JCO.2004.02.175

Thomas, J. S., \& Kabbinavar, F. (2015). Metastatic clear cell renal cell carcinoma: A review of current therapies and novel immunotherapies. Critical Reviews in Oncology and Hematology, 96(3), 527-533. http://doi.org/10.1016/j. critrevonc.2015.07.009

Thorstenson, A., Harmenberg, U., Lindblad, P., Holmstrom, B., Lundstam, S., \& Ljungberg, B. (2015). Cancer characteristics and current treatments of patients with renal cell carcinoma in Sweden. BioMed Research International, 2015, article ID 456040. http://doi.org/10.1155/2015/456040

U.S. Department of Health and Human Services. (2010). Common Terminology Criteria for Adverse Events (CTCAE) Version 4.0. Retrieved from https://evs. nci.nih.gov/ftp1/CTCAE/CTCAE_4.03_2010-06-14_ QuickReference_5x7.pdf

Yada, M., Masumoto, A., Motomura, K., Tajiri, H., Morita, Y., Suzuki, H., \& Koyanagi, T. (2014). Indicators of sorafenib efficacy in patients with advanced hepatocellular carcinoma. World Journal of Gastroenterology, 20(35), 1258112587. http://doi.org/10.3748/wjg.v20.i35.12581

Zanardi, E., Grassi, P., Cavo, A., Verzoni, E., Maggi, C., De Braud, F.,...Procopio, G. (2016). Treatment of elderly patients with metastatic renal cell carcinoma. Expert Review of Anticancer Therapy, 16(3), 323-334. http://doi.org $/ 10.1586 / 14737140.2016 .1131613$ 